\title{
Yegor Gaidar: Pragmatic Economist or Romantic Revolutionary?
}

\author{
GENNADI KAZAKEVITCH ${ }^{1}$
}

\section{The Controversy}

Immediately after the life of any prominent person comes to an end, unalloyed tributes normally flow. Not surprisingly this happened for Yegor Gaidar, both in the Western media and on Russian internet sites of all political persuasions. But there was one difference: the obituaries, both in English and in Russian, reveal how divided public opinion was on the man and his influence.

"If a new Managing Director took over a large sluggish company and caused its value to shrink drastically, you'd call them a bungler, or at best unlucky. So why is Gaidar viewed as a hero?"

"I admire such strong personalities as Yegor Gaidar was — [a man] who is able to perform a great deed and not be afraid of the responsibility." 2

These are from a Western source. In Russia, a former mayor of Moscow, Gavriil Popov, and the current mayor, Yury Luzhkov, claimed that Yeltsin appointed Gaidar as Acting Prime Minister in 1992 only under pressure from the United States, and a promise of tens of billions of dollars in aid (Popov and Luzhkov 2010). They added: “The failure of Gaidar's model [of reform] was inevitable because it was based on a wrong theory, and did not correspond to the fundamental reality predetermined by socialism in Russia."

In response, one of the most prominent Russian liberal journalists and dissidents Valeria Novodvorskaya (2010) writes: "Gaidar [is] our personal Saviour who opened the door for us to the capitalist Paradise."

\footnotetext{
1 Monash University, Gennadi.Kazakevitch@buseco.monash.edu.au. The author is grateful to William Coleman for his encouragement in writing this article, and to the insightful suggestions and stimulating comments of the anonymous referee, Anna Taitslin and Luba Torlina.

2 These two quotes are drawn from The Economist, 17 December, 2009, at: http://www.economist.com/ node/15125467/comments.
} 
The fierce debate, almost 20 years after Gaidar's short term as Prime Minister of the first post-communist government, over his contribution to both the building of the new Russian statehood and to the theory and economic history of postcommunist transformation, only reflects how important Gaidar was to Russia, both as a politician and an academic.

This article attempts to place Gaidar's role in contemporary Russia beyond partisan debate. It is predominantly based on Gaidar's own key publications (Gaidar 2000-2007) and also reflects the author's personal recollection of Gaidar's intellectual and professional environment, from the 1970s to the early 1990s. ${ }^{3}$

\section{The Life}

Yegor Gaidar was born in 1956. The history of Soviet Russia and Gaidar's family heritage were closely interrelated. Both his grandfathers, Arkadiy Gaidar and Pavel Bazhov, fought with the Red Army in the Civil War. Both became very famous - indeed, iconic - Soviet writers, whose books have been widely read by several generations of children and adolescents. Both lived through Stalin's industrialisation, the Great Terror and the Second World War. Arkadiy Gaidar fell in the war against the Nazis, as a member of the poorly equipped home guard that was hurriedly recruited to defend Moscow in the autumn of 1941. Pavel Bazhov, a school teacher, miraculously avoided imminent arrest in 1938 (Gaidar 2000: Chapter 1), and thereafter lived a life of seclusion as a homebound writer.

Gaidar's father, Timur, was a prominent military journalist and held the military rank of a 'one star' admiral, a very high, but not unprecedented, rank for Pravda's military correspondent. Since Yegor's death, speculation has resurfaced that his father's 'real' occupation was in the intelligence service. Though such speculation cannot be proved nor disproved, considering Timur Gaidar's military rank and his array of postings to 'hot spots', it is perhaps fair to assume that, if he was affiliated to any intelligence service, then his real master most probably was the GRU (Military Intelligence Directorate), rather than the KGB. Military journalist or military/naval attaché was the usual cover of a GRU officer. GRU personnel used any opportunity to distance themselves from the political spying activities of the KGB, and regarded themselves as a high-level professional intelligence community. They were indeed more liberal-

3 The author knew Yegor Gaidar from his student days at Moscow State University, and throughout the 1970s-1980s in the circles of professional economists in Moscow. He had a lengthy conversation with Gaidar during the latter's visit to Australia in 1996. 
minded and more outspoken. Reinforcing the understanding of Yegor Gaidar's upbringing within the elite Soviet establishment, this is also an indicator of relatively non-orthodox critical thinking within his family circle.

As a child Yegor travelled to Cuba, where his father was posted, and was living there during the Missile Crisis of 1962. He later wrote of the 'revolutionary and enthusiastic' Havana of that time (Gaidar 2000). Like most Russian children of his generation, he believed the Soviet Union to be the best country in the world. That is why he was surprised when he arrived in Yugoslavia in 1966, on another of his father's postings, to discover a socialist country with a market economy, open public discourse and fully stocked shops. That was the time Gaidar began to follow economic news, and to ask questions about Yugoslavian economic reforms. In addition, his father, who noticed his son's aptitude with numbers, entrusted the 10-year-old with keeping monthly business expenditure reports. That was the beginning of Gaidar the economist.

As for many youngsters of that time, Gaidar's comfortable childhood in a privileged family and a beautiful country was broken in August 1968 when Warsaw Pact countries, headed by the Soviet Union, invaded Czechoslovakia to suppress the Prague Spring movement. This caused Gaidar to question what kind of truth it was that needed to be imposed on people with the help of tanks (Gaidar 2000).

\section{The Scholar}

The generation of young Russian intellectuals of the late 1960s — who had to grapple with the Yugoslavian deviation from the Soviet model, Euro-socialism, the Prague Spring and, finally, radical economic reform in Hungary - did not lose their belief in 'socialism proper'. Not surprisingly, they were initially seeking answers through comprehensive studies of the Marxist literature. This was also facilitated by the liberal and creative atmosphere - despite strict ideological control - in the best educational institutions in the capital and major provincial cities. Paradoxically, the elite layer of the educational system, established mostly for the children of the privileged members of Soviet society, created the generation of people who ultimately rejected the very principles of the Soviet system.

Yegor Gaidar graduated from the Economics Faculty of Moscow State University, which was by all accounts the best school of economics and one of the sources of liberal economic thought in the Soviet Russia of the 1960s-1980s. This was only possible because the controversial and eclectic structure of the curriculum included both orthodox Marxian theory, as interpreted by Soviet ideological apparatus, and contemporary Western economics. Along with studying - 
almost by heart — the works of Marx, Engels, Lenin, and the Communist Party of the Soviet Union, students were exposed to a variety of courses in modern conventional economics screened by titles that were inoffensive to 'ideological controllers'. Thus, under the title 'Critics of Western Economic Thought', a decent programme in contemporary economic thought was taught; under 'Mathematical Economics', there was contemporary neoclassical microeconomics; under 'Advanced Macro-econometrics' there was contemporary monetary economics; 'Socialist Planning and Forecasting' taught the principles of macroeconomics, and furthermore, why the Soviet planning system did not work. In the early 1970s Professor Shatalin, who lectured on the latter course (and who later became the mentor of both Gaidar and the author of this article), dared to explain to his students behind closed doors that the Soviet economy was about to collapse, and the only reason it had not done so already was the revenue it received from its oil exports.

Meanwhile, even the most liberal economic tendency in Russia originated from the 'intelligentsia' educated within the Marxian ideological environment and for this reason tried to explain the failure of the Soviet system and find a way to improve it, initially, within the Marxian paradigm. That is why the concepts of the socialist economy or socialist planning were essential for the liberal economic discourse. Furthermore, Gaidar and his fellow young reformers were educated in the 'Marxist' belief that it was possible to reform the economy by revolutionary socio-economic engineering. In fact, the community of progressive economists was implicitly divided between two major schools of thought (both of them, of course, considered to be 'heretical' by the orthodox Marxists). One, founded by the prominent mathematician and Nobel Prize winner Leonid Kantorovich, was essentially socio-economic engineering on account of both its philosophy and its proposed technology of planning. It believed that a large-scale optimal-planning model could be seen as a prototype of an optimal national plan; and the price variables of that model as the prototypes of regulated prices. Therefore, the national planning process could be formalised as the optimal solution of a largescale optimisation problem, making a centrally planned economy as efficient as a market economy (Kantorovich 1959). As utopian as it may sound, this approach nevertheless opened the door to studies in Western microeconomic theory, and so to an understanding of the infeasibility of optimal planning. And so the way was opened to the second, alternative school of thought, which favoured the introduction (and, once again, socio-economic engineering) of some elements of a market mechanism, without dismantling its socialist foundations. And this is where Gaidar, like many of his fellow students, started to ask himself further difficult questions about the feasibility of market socialism.

For Gaidar, those questions were even more difficult and important because of his experience with Yugoslavia; how to ensure that firms under the management 
of workers would create new jobs; how to ensure that capital would be appropriately re-distributed to new, more efficient, ventures; how to solve the problem of sharply differentiated wages; and whether it would be possible to avoid accelerating the unemployment and inflation that had been endemic to Yugoslavia for decades. Though Gaidar was fluent in English, Spanish and Slovenian, he was seemingly unaware of the theory of the labour-managed firm, well known among Western economists. Such firms maximise profit per employee, but not the volume of profit. Consequently, if they prevail in an economy, as was the case in Yugoslavia, they restrict employment, accelerate inflation, and also are a major impediment to economic growth (Ward 1958). Despite being unaware of this gloomy theoretical prediction, Gaidar came to the general conclusion that any form of socialism was imminently destined to fail: while state socialism was a base for the absolute power of bureaucracy, market socialism obviously demonstrated its inefficiency (Gaidar 2000: Chapter 2). Paradoxically, however, as a scholar Gaidar never broke with Marxian methodology. Even during his time after politics as one of the greatest reformers of his era, who rejected the Marxian criticism of capitalism and adopted the transition to a market economy for his country, he maintained the Marxian deterministic explanation of the genesis of economic systems by the development of productive forces, despite the recent historic experience and contemporary literature (Shlyapentokh 2005).

\section{The Reformer}

As a young university graduate, Gaidar was fortunate to be able to start earning a living as a full-time researcher at the Institute of System Research - an elite think-tank in Moscow - in the area that interested him most. He continued to research into liberalising economic reforms in the socialist countries. However, it would be incorrect to think that from a young age Gaidar was developing into a dissident, anticommunist, pro-market economist. On the contrary, for a decade and a half he was an establishment insider and a member of the Communist Party until its dissolution in August 1991. Furthermore, during the time of Gorbachev's liberalisation, Gaidar was working for the party's official daily, Pravda, and for the thrice-weekly Communist.

Together with many younger and progressive members of the Party, Gaidar embraced the changes that became possible during Gorbachev's time, when radical economic reforms moved out of liberal academic discussion circles to be placed on the agenda of the government of the day. He found himself in the right place at the right time when a commission was established, under the umbrella of the Politburo of the central Committee of the Communist Party, to look at how to improve the management of the economy. The scientific support of the Commission was entrusted to the Institute of System Research and, more 
specifically, to the department Gaidar was working with. Together with his colleagues, Gaidar became not just a witness to, but instrumental in facilitating, the gradual introduction into the official language of such terms as 'radical economic reform', 'market', 'individual entrepreneurship', 'cooperative', 'joint venture', as well as 'unemployment', 'inflation', 'poverty', 'social stratification' and 'budget deficit'.

At the same time, the practical official decision-making was incompatible with economic reforms, of which the acceleration of capital investments and growth were declared to be the key strategies. Gaidar was trying hard to promote the idea that liberal reform and financial stabilisation - rather than growth or ambitious new investment projects that would lead to further destabilisation - should be the first priority. He wrote one submission after another and met Gorbachev several times. Unfortunately, while Gorbachev was looking favourably at numerous proposals from liberal academics, he was also under ideological pressure from his conservative Party apparatus, and yielded to compromised, unworkable solutions. This led to an inevitable disaster.

By the late 1980s the Soviet Union was facing deep economic crisis and collapse. For quite a long time before that the economy had been able to survive primarily through exporting energy resources. However, world prices for crude oil, which had been sharply increasing in the late 1970s, fell substantially between 1981 and 1987. This created the threat of a total deficit of final consumer goods, as Russia was largely dependent on energy exports for importing some basic consumer needs, such as food.

Moreover, Russia's situation could not be salvaged by its gold reserves. The communist regime had inherited about 1300 tons of gold from the prerevolutionary Russian government. In spite of massive investments in the production of gold, the first post-communist government of 1991 found itself the inheritor of just 286 tons. ${ }^{4}$ Nor did the US\$63 billion of Western credit help. But it did triple the level of foreign debt. Starting from the second half of 1991, grocery shops became empty. Even the queues disappeared - there was nothing to queue for. Famine seemed inevitable.

\section{The Politician}

This was the situation in the country when Gaidar embarked on his short but historically influential career as a top public servant. In 1991 he joined Yeltsin's government, as First Vice-Premier of the Russian Government and Minister of

4 Here and below, unless otherwise stated, the data or estimates are from, or are based on, the Goskomstat website: www.gks.ru. 
Economics from 1991 until 1992, and Minister of Finance from February-April 1992. He became Acting Prime Minister for a few months in 1992. However, the position was not confirmed by the anti-reform majority of the Congress of People's Deputies, and that was the beginning of the end of his career as a politician. Subsequently, he was active in advising the government, was a member of the right-wing political movement, and, for some time, was a member of the Duma. Mostly, though, he concentrated on academic work as the founding director of the Institute for the Economy in Transition and was a prolific writer on the theory of reform and Russia's economic history.

Gaidar's 'failure' to become a career politician was perhaps attributable to the fact that he was not a politician by nature. From his student years he was in many ways a typical scholar. Though he was softly spoken and quite introverted, he was confident in his beliefs. He could impress those who valued knowledge and logic but he lacked the charisma required to convince a broader audience. He spoke the language of economics and political science but could rarely translate it into slogans and spin. He was definitely an academic leader, but not a leader of a mass political movement that would be able to embrace the majority of the nation. Though he was born into and served the official establishment, he was a stranger to it, and was rejected by it for his incompatibility with either the prevailing system or prevailing persuasion of the day.

\section{The Transition}

In order to order to understand the much-debated issue of Gaidar's role in the revolutionary economic transformation of early 1990s, let us have a look at the facts. The imminent catastrophe of 1992 could be addressed in only one of two possible ways - by introducing traditional rationing supported by the introduction of martial law, or by radically liberalising the economy. Neither of the options was absolutely free of risk of mass unrest and the loss of human life. Gaidar chose liberalisation. He considered this a lesser risk, and the only way to prevent civil war, riots and the possibility of a return to Stalinism. Indeed, his choice meant that the country was saved from collapse, but Gaidar never received the praise that was his due from the majority of the Russian people. At the same time, Russia was plunged into an inevitable transitional depression, and Gaidar has been blamed for this ever since.

Meanwhile, even among Gaidar's strongest supporters, the accent on his polices and achievements is somewhat biased. Firstly, he is both most praised and most blamed for price liberalisation. However, this measure represented the consensus of the day among all political forces, including the communists, and was approved by an absolute majority at the Congress of People's Deputies, in October 1991. 
Prices would have been liberalised anyway, with or without Gaidar. Secondly, he is blamed for the devaluation that reduced household savings to almost nonexistence. Indeed, while price liberalisation contributed to the devaluation, the fact of the matter is that the most considerable devaluation (by 150 per cent) occurred in 1991 — before Gaidar joined the Government.

At the same time, it is almost forgotten that Gaidar rebuilt the country's fiscal system from scratch — replacing the collapsed Soviet-era system - a contribution which Gaidar himself saw as his government's major achievement. Within the space of a few weeks, the new package of legislation was drafted and approved by the legislature, and the budget was saved from imminent collapse. However, paradoxically, the right-wing liberal economist Gaidar is now criticised for his soft budgetary policy. Gaidar himself explained that too radical spending cuts would undermine already fragile social stability.

Gaidar is blamed for 'shock therapy' that caused a deep plunge in the Russian economy. Deregulation of most prices, as well as sharp measures towards opening the economy and the convertibility of the Russian currency, allowed for rapid elimination of shortages and queues. At the same time, the economy experienced severe post-communist stagflation. In the period 1992-96, GDP decreased by 40 per cent and industrial production by 50 per cent. The price level increased up to 26 times, and increases in nominal wages were much slower than increases in the CPI. This caused a 26 per cent drop in real income, which was accompanied by a considerable stratification within society (Kazakevitch and Smyth 2005).

In fact, Gaidar had time only to save the country from collapse by imposing his macro-financial shock, but was not given the chance or time to undertake the subsequent therapy by restructuring the economy at the micro level. The subsequent privatisation was designed on principles that Gaidar did not entirely agree with, and was conducted mostly after his time in government. It led to an ownership structure whereby at the end of 1990s 70-75 per cent of capital was owned by a mixture of private and government entities. However, only 30 per cent was owned purely by private persons or independent corporate institutions; the government had total ownership of up to 25 per cent of capital assets and part ownership of another 45 per cent (Kazakevitch and Smyth 2005). Under Putin, government control of the key revenue-earning sectors was consolidated much further.

In order to appreciate how radical the reforms have been and how the market has been created, the nature and structure of the privatised assets in the industrial sector should be noted. The pre-reform Soviet Union used to be an industrialised nation with a rather well-developed production apparatus. This apparatus mostly consisted of large and inefficient industrial giants, which 
had been established on the orders of the strictly centralised planning system with the aim of serving the needs of the military machine rather than the final consumer.

The corporatisation and privatisation of large industrial enterprises alone could not solve the problem of efficiency and competition. A considerable physical restructuring of assets was necessary to meet the demands of the emerging market. The large government share of ownership, together with the lack of both domestic and foreign investors' trust in political stability and the future of the market economy in Russia, did not help in efforts to make the manufacturing sector competitive in the domestic or international markets. The level of foreign investment today remains disproportionately low, and the outflow of domestic finances abroad continues. The Russian trade balance and the federal budget continues to rely on the export of fuel and some other mineral resources, and, as such, are strongly dependent on fluctuating world oil and gas prices.

In conclusion, almost 20 years after Gaidar's reform, non-democratic Russia is once again faced with an inefficient economy and an uncertain future. This is in spite of Gaidar's endeavours, not the result of them.

\section{References}

Ward, B. 1958, 'The Firm in Illyria: Market Syndicalism', American Economic Review.

Gaidar, Yegor 2000, Days of Defeat and Victory, Seattle, WA: University of Washington Press.

Gaidar, Yegor 2003, State and evolution: Russia's search for a free market, translated by Jane Ann Miller, Seattle and London: University of Washington Press: xv and 139.

Gaidar, Yegor 2004, 'Recovery Growth and Key Features of the Current Economic Situation in Russia', Problems of Economic Transition 46(10): 6-23.

Gaidar Yegor 2005, Dolgoye vremya. Rossia v mire: ocherki economicheskoy teorii (Long Time. Russia in the World: Essay on Economic Theory), Moscow: Delo (in Russian).

Gaidar, Yegor 2005 'Development Challenges in the 1990s' in Leading Policymakers Speak from Experience, Washington, D.C.: World Bank; New York: Oxford University Press. 
Gaidar, Yegor 2007, Collapse of an Empire: Lessons of Modern Russia, The Brookings Institution.

Kantorovich, L. V. 1959, Ekonomicheskii raschet nailuchshego ispol'zovaniya resursov, Izdatestvo Akademii nauk SSSR. English translation: The Best Use of Economic Resources, Harvard University Press, 1965.

Kazakevitch G. and Smyth R. 2005, 'Gradualism versus Shock Therapy: (Re) Interpreting the Chinese and Russian Experience', Asia Pacific Business Review 22(1).

Novodvorskaya, Valeria 2010, 'The Reforms that Choose Us', at: http://www. grani.ru/opinion/novodvorskaya/m.176038.html.

Popov, Gavril and Luzhkov, Yury 2010, 'One more Word about Gaidar', Mosckovskiy Komsomolets, 21 January 2010, at: http:/www.mk.ru/politics/ article/2010/01/21/416001-esche-odno-slovo-o-gaydare.html.

Shlyapentokh, V. 2005, 'Is Egor Gaidar a Marxist?! (on Gaidar's book A Long Time)', Voprosi Economiki 10. 